DOI: $10.2478 / \mathrm{v} 10025-012-0002-3$

JOURNAL OF WATER

AND LAND DEVELOPMENT

J. Water Land Dev. No. 15, 2011: 19-28

\title{
The land use changes in agricultural areas between 1980 and 2005 \\ with particular emphasis on permanent grasslands \\ - an example of the upper Raba River basin
}

\author{
Marek KOPACZ, Stanisław TWARDY
}

Institute of Technology and Life Sciences at Falenty, Małopolska Research Centre in Kraków, 31450 Kraków, ul. Ułanów 21B, phone/fax +48 12 412-84-59, e-mails: m.kopacz@itep.edu.pl, s.twardy@itep.edu.pl

\begin{abstract}
The aim of this study was to evaluate changes in the agricultural land use with particular focus on pastures and meadows in relation to transformation in agriculture in selected communes located in mountain areas of the Raba River catchment. Changes in husbandry were described with production parameters such as animal stock (expressed in LU) and NPK load originating from all agricultural sources. The area of agricultural lands, particularly arable lands, decreased in the years 1980-2005 but meadow areas increased. A close relationship was shown between the reduction of agricultural production, expressed in animal stock, and changes in NPK loads. The conclusions from the paper will help shaping the functional space in mountain areas and sustainable development there.
\end{abstract}

Key words: agricultural use, animal stock, arable lands, NPK load, permanent grasslands

\section{INTRODUCTION}

The Carpathian areas underwent particularly intense structural transformation, mainly in agricultural production, infrastructure, and environmental changes in the structural space. This affected the structure of land use, both within the agricultural areas and in their proportion to non-agricultural lands, mainly urban areas and technical infrastructure. These transformations had their roots in socio-economic changes after 1989 and in Poland's access to the structures of the European Union in 2004 and resulted in many processes of natural and anthropogenic origin (KOPACZ, 2007; TWARDY, 2008; 2009).

The Carpathians are characterised by large amounts of water resources. The above mentioned transformations influenced the quality of aquatic environment, especially of surface waters, which are very sensitive to human impact and reflect spatial and structural changes (GUZIK, 1995; SYMONIDES, 2007). 
The aim of this study was to evaluate changes in agricultural use over a long period of time with particular emphasis on pastures and meadows. The assessment was based on transformation in agriculture, which took place in the mountain Raba River catchment. The changes were described with some production parameters such as livestock density expressed by the Livestock Unit (LU) per ha and the total inflow of nutrients from agricultural sources in the catchment area (kg NPK/AL).

\section{MATERIAL AND METHODS}

The structural and performance parameters used in the statistical analysis in most cases were compiled in the administrative layout. The statistical data obtained from each commune situated in the upper Raba River catchment basin were converted into individual parts of the basin. This was done with the use of a matrix conversion, which calculated the proportions between common areas of studied communes and parts of the catchment areas.

The study area was the upper Raba River basin up to the cross-section in Dobczyce. Its total area amounted 768 square $\mathrm{km}$. The catchment is characterised by a specific orography, landscape, climate and hydrography. For these reasons the study catchment is representative for the central part of the Polish Carpathians (DYNOWSKA and MACIEJEWSKI, 1991; DYNOWSKA, 1995). Its area includes several geomorphological regions: Brama Sieniawska, Beskid Sądecki, Wyspowy and Żywiecki and Pogórze Wiśnickie. The Raba River is a right-bank tributary of the Vistula River. Its springs are located at an elevation of $785 \mathrm{~m}$ above sea level on the slopes of Obidowa Mountain. About $86 \%$ of the Raba River basin is located in the Beskid Mountains, which qualifies this area to the typical mountain catchments (NIEDBAŁA and CZULAK 2000).

Analysed catchments, their areas and measuring cross-sections are listed in Table 1 and presented in Figure 1.

Table 1. Analysed catchments and measuring cross-sections in the upper Raba River basin

\begin{tabular}{c|lcc|c}
\hline $\begin{array}{c}\text { Number } \\
\text { of measuring section }\end{array}$ & River & $\begin{array}{c}\text { Area of catchment above the } \\
\text { measuring cross-section, } \mathrm{km}^{2}\end{array}$ & $\begin{array}{c}\text { Place of measuring } \\
\text { cross-section }\end{array}$ \\
\hline 1 & Raba & 27.4 & Raba Wyżna \\
2 & Raba & 685.0 & Osieczany \\
3 & Raba & 768.0 & Dobczyce \\
4 & Mszanka & 167.0 & Mszana Dolna \\
5 & Krzczonówka & 87.9 & Krzczonów \\
6 & Trzebuńka & 33.0 & Stróża \\
7 & Bysinka & 14.9 & Myślenice \\
8 & Trzemeśnianka & 29.1 & Banowice \\
\hline
\end{tabular}




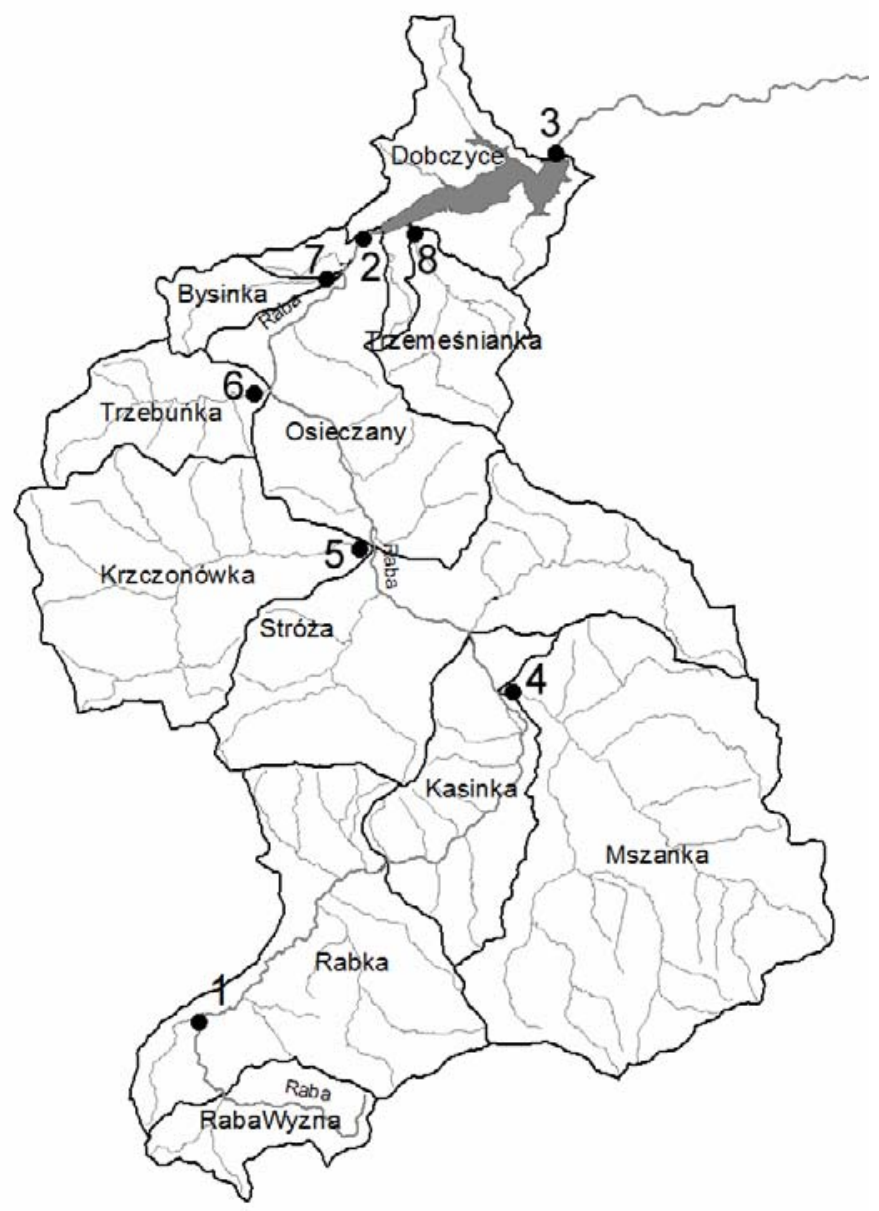

Fig. 1. Spatial distribution of the measurement stations in the upper Raba River basin

Data from the years 1980-2005 on the land use structure and parameters describing the agricultural production were obtained from the Regional Statistical Office in Kraków. Data were collected from 15 communes (Dobczyce, Dobra, Jordanów, Lubień, Mszana Dolna, Myślenice, Niedźwiedź, Nowy Targ - rural part, Pcim, Raba Wyżna, Rabka-Zdroj, Siepraw, Tokarnia, Wieliczka, and Wiśniowa) situated entirely or in part in the upper Raba River basin. The numerical values of the parameters were converted from an administrative system to different parts of the study catchments listed in Table 1. The load of nutrients from agricultural sources (NPK load) was calculated using a computer programme MACROBIL. The relationships between land use factors and structural parameters were determined by linear or nonlinear regressions. The regressions of the highest statistical significance were selected for further analyses (ELAND, 1964; GREŃ, 1982). 


\section{RESULTS AND DISCUSSION}

The structure of agricultural land use underwent significant changes in the upper Raba River basin most pronounced in the surface area of arable lands and grasslands, especially in meadow areas. Table 2 shows the changes in the agricultural land use in selected parts of the upper Raba River basin.

Table 2. Changes in agricultural land use in the upper Raba River basin in the years 1980-2005 (in per cent of the total area)

\begin{tabular}{|c|c|c|c|c|c|c|}
\hline \multirow{2}{*}{ Sections } & \multicolumn{6}{|c|}{ Years } \\
\hline & 1980 & 1985 & 1990 & 1995 & 2000 & 2005 \\
\hline \multicolumn{7}{|c|}{ Agricultural lands } \\
\hline Raba-Dobczyce & 55.2 & 54.5 & 54.1 & 48.6 & 47.3 & 44.2 \\
\hline Raba - Osieczany & 51.0 & 50.3 & 50.3 & 47.1 & 46.0 & 42.6 \\
\hline Raba - Raba W. & 58.7 & 58.7 & 58.9 & 58.9 & 45.7 & 40.2 \\
\hline Trzemeśnianka & 73.0 & 72.7 & 71.5 & 53.2 & 50.8 & 46.5 \\
\hline Bysinka & 71.2 & 71.0 & 69.5 & 53.3 & 50.5 & 43.0 \\
\hline Trzebuńka & 49.8 & 49.4 & 49.3 & 41.9 & 41.7 & 39.8 \\
\hline Krzczonówka & 52.6 & 52.3 & 52.3 & 46.9 & 47.4 & 46.9 \\
\hline Mszanka & 44.7 & 43.5 & 43.9 & 42.4 & 42.5 & 42.7 \\
\hline \multicolumn{7}{|c|}{ Arable lands } \\
\hline Raba - Dobczyce & 45.1 & 44.3 & 42.9 & 37.8 & 36.1 & 26.6 \\
\hline Raba - Osieczany & 42.3 & 41.5 & 40.4 & 37.1 & 35.5 & 24.8 \\
\hline Raba - Raba W. & 46.8 & 46.9 & 47.0 & 47.0 & 29.6 & 19.7 \\
\hline Trzemeśnianka & 56.2 & 55.5 & 54.0 & 38.5 & 36.7 & 31.3 \\
\hline Bysinka & 55.3 & 55.3 & 53.8 & 40.3 & 40.4 & 33.3 \\
\hline Trzebuńka & 41.5 & 41.5 & 41.3 & 31.6 & 31.4 & 28.4 \\
\hline Krzczonówka & 44.4 & 44.0 & 43.8 & 38.4 & 38.2 & 34.9 \\
\hline Mszanka & 36.3 & 34.3 & 30.9 & 30.0 & 30.0 & 16.1 \\
\hline \multicolumn{7}{|c|}{ Grasslands } \\
\hline Raba - Dobczyce & 8.9 & 9.2 & 9.9 & 9.8 & 10.3 & 17.1 \\
\hline Raba - Osieczany & 7.9 & 8.0 & 8.9 & 9.2 & 9.9 & 17.4 \\
\hline Raba - Raba W. & 11.5 & 11.5 & 11.6 & 11.6 & 15.9 & 20.2 \\
\hline Trzemeśnianka & 13.2 & 14.4 & 14.1 & 12.4 & 12.1 & 13.5 \\
\hline Bysinka & 11.8 & 12.4 & 12.3 & 10.7 & 7.8 & 7.5 \\
\hline Trzebuńka & 7.1 & 6.8 & 6.8 & 9.3 & 9.9 & 11.1 \\
\hline Krzczonówka & 8.0 & 8.2 & 7.9 & 8.0 & 9.0 & 11.9 \\
\hline Mszanka & 7.7 & 8.4 & 12.1 & 11.5 & 11.6 & 26.3 \\
\hline
\end{tabular}

Surface area of agricultural lands in the upper Raba River catchment decreased by about $11 \%$. Only in the catchment closed by the cross-section Raba Wyżna it decreased by almost 20 per cent. In catchments of the Raba River tribu- 
taries the reduction of the agricultural area was larger. For example in the Bysinka River catchment it amounted about $25 \%$ and in the Trzemeśnianka River catchment - even $30 \%$.

The largest reductions in surface area of agricultural lands pertained to arable lands. These areas decreased by 20 to $30 \%$ in some cases. The surface area of meadows increased and that of pastures - slightly decreased at the same time (Figs 2 and 3$)$.

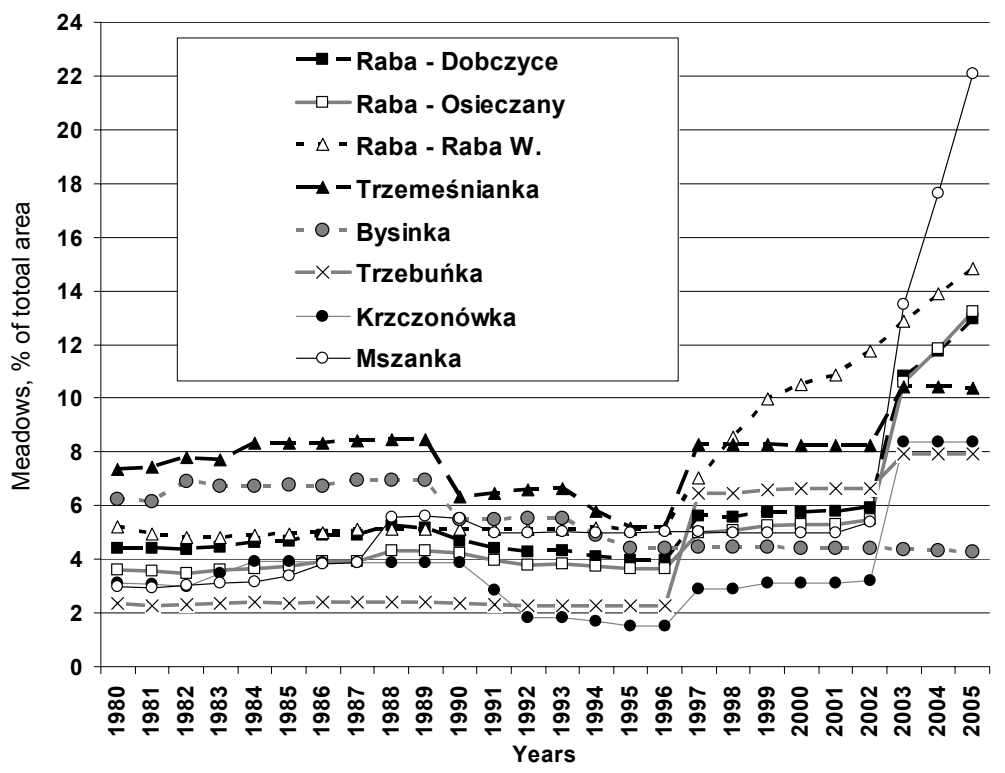

Fig. 2. Changes in the surface area of meadows in the upper Raba River basin

These changes resulted from the fact that some arable lands were transformed into permanent grasslands, particularly meadows. In many cases, the agricultural lands due to natural plant succession turned out into meadows which are now extensively used or abandoned. Hence, in practice such meadows can be named "the sod areas". The conversion of arable lands into grasslands only partially explains the observed changes. The decrease of the surface area of agricultural lands in the upper Raba River basin (by c. 20\%) means that a large part of arable lands transformed into non-agricultural areas (e.g. to lands of ecological use), or were completely degraded and qualified as wastelands. The latter may be represented by the Dobczyce dam reservoir created in 1986 in northern part of the upper Raba River basin and classified (the Main Statistical Office) as wasteland.

The changes in animal stock (expressed in LU) and NPK load from agricultural sources (expressed in elemental nitrogen, phosphorus and potassium) are shown in Table 3. 


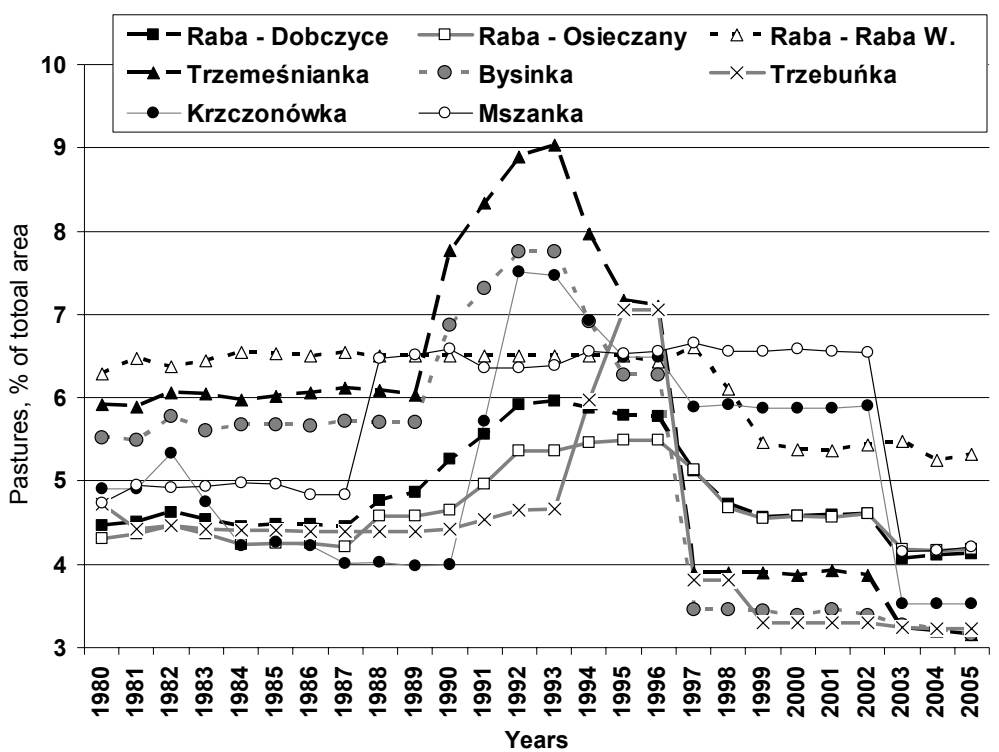

Fig. 3. Changes in the surface area of pastures in the upper Raba River basin

Table 3. Changes of animal stock and NPK load in the upper Raba River basin

\begin{tabular}{l|c|c|c|c|c|c}
\hline \multirow{2}{*}{\multicolumn{1}{c}{ Cross sections }} & \multicolumn{6}{c}{ Years } \\
\cline { 2 - 7 } & 1980 & 1985 & 1990 & 1995 & 2000 & 2005 \\
\hline Raba - Dobczyce & 1.15 & 1.09 & 1.03 & 0.91 & 0.75 & 0.39 \\
Raba - Osieczany & 1.18 & 1.12 & 1.06 & 0.95 & 0.79 & 0.42 \\
Raba - Raba W. & 1.35 & 1.26 & 1.22 & 1.05 & 1.06 & 0.58 \\
Trzemeśnianka & 1.01 & 0.91 & 0.88 & 0.78 & 0.61 & 0.31 \\
Bysinka & 0.99 & 0.85 & 0.80 & 0.71 & 0.57 & 0.30 \\
Trzebuńka & 1.04 & 0.93 & 0.83 & 0.75 & 0.60 & 0.28 \\
Krzczonówka & 1.17 & 1.03 & 0.98 & 0.87 & 0.71 & 0.37 \\
Mszanka & 1.25 & 1.21 & 1.14 & 1.07 & 0.89 & 0.43 \\
& $\mathrm{NPK}$ load, kg NPK per hectare AL & & & \\
Raba - Dobczyce & 302.8 & 285.9 & 241.8 & 223.9 & 189.1 & 123.2 \\
Raba - Osieczany & 307.7 & 292.1 & 248.0 & 230.6 & 195.7 & 126.4 \\
Raba - Raba W. & 335.4 & 320.4 & 277.8 & 254.3 & 239.0 & 157.1 \\
Trzemeśnianka & 277.7 & 252.3 & 214.5 & 200.0 & 163.8 & 115.1 \\
Bysinka & 277.0 & 244.8 & 204.8 & 191.4 & 160.5 & 118.1 \\
Trzebuńya & 275.6 & 244.7 & 206.9 & 192.0 & 158.4 & 109.6 \\
Krzczonówka & 299.2 & 266.1 & 224.4 & 213.1 & 180.3 & 122.8 \\
Mszanka & 326.0 & 315.3 & 254.2 & 243.6 & 207.0 & 117.6 \\
\hline
\end{tabular}


A clear reduction of the livestock density was observed in the study period. Compared with the 1980 s the livestock decreased from $1.0-1.4$ to $0.2-0.6 \mathrm{LU} \cdot \mathrm{ha}^{-1}$. The total load of NPK was also reduced from an average of 300 to about $124 \mathrm{~kg}$ NPK per hectare of arable lands. Most pronounced changes in animal stock and NPK loads began in the second half of the 1990s.

There was a clear linear relationship between the stocking density and the reduction in arable lands (Fig. 4). Similar, but inversely proportional relationship was found for grasslands (Fig. 5). Relationships between the area of arable lands and grasslands and the load of NPK are presented in Table 4.

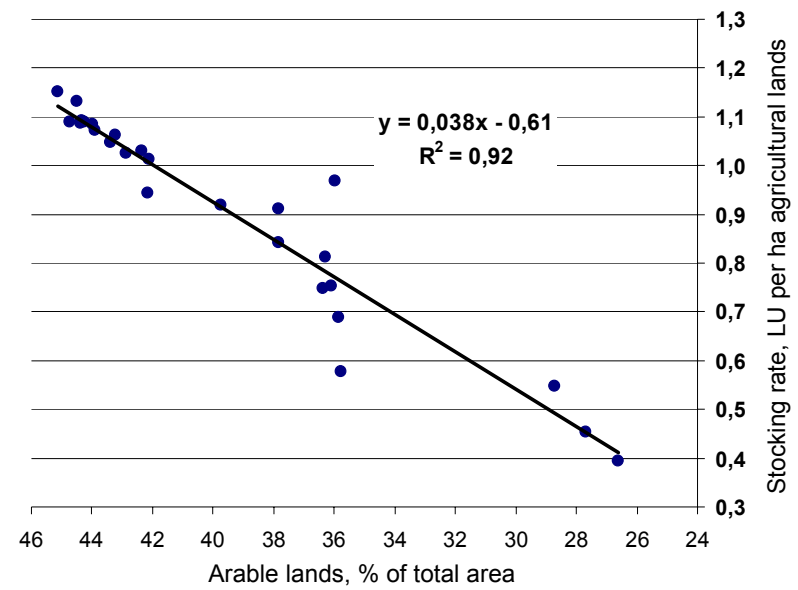

Fig. 4. The relationship between stocking density $\left(\mathrm{LU} \cdot \mathrm{ha}^{-1}\right)$ and percent of arable lands in the upper Raba River catchment

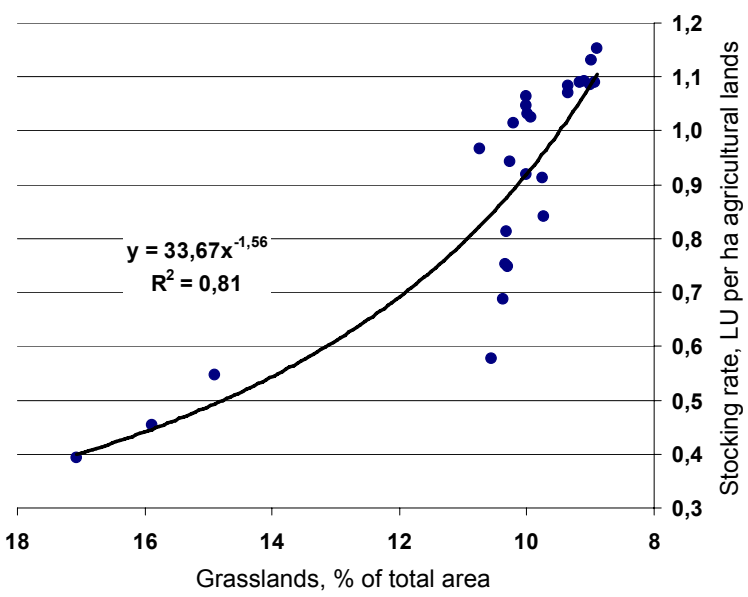

Fig. 5. The relationship between stocking density $\left(\mathrm{LU} \cdot \mathrm{ha}^{-1}\right)$ and percent area of grasslands in the upper Raba River catchment 
Table 4. The regression of NPK load on the area of arable lands and grasslands in the upper Raba River catchment

\begin{tabular}{l|l|c|c|c}
\hline \multirow{2}{*}{ Section } & \multicolumn{2}{c|}{ Arable lands } & \multicolumn{2}{c}{ Grasslands } \\
\cline { 2 - 5 } & \multicolumn{1}{c|}{ equation } & $R^{2}$ & equation & $R^{2}$ \\
\hline Raba Dobczyce & $y=36.24 \mathrm{e}^{0.046 x}$ & 0.90 & $y=5041.2 x^{-1.34}$ & 0.74 \\
Raba- Raba Wyżna & $y=28.088 x^{0.6}$ & 0.71 & $y=3333 x^{-1.0001}$ & 0.76 \\
Trzemeśnianka & $y=4.63 x-10.23$ & 0.82 & - & - \\
Bysinka & $y=5 x-38.54$ & 0.73 & $y=79.28 \mathrm{e}^{0.08 \mathrm{x}}$ & 0.53 \\
Trzebuńka & $y=0.67 x^{1.57}$ & 0.74 & $y=2418.7 x^{-1.21}$ & 0.76 \\
Krzczonówka & $y=12.97 x-316.5$ & 0.75 & $y=8598.8 x^{-1.71}$ & 0.69 \\
Mszanka & $y=0.6 x^{2}-19.93 x+280.2$ & 0.89 & $y=1968.6 x^{-0.88}$ & 0.85 \\
\hline
\end{tabular}

Regression equations from Table 4 represent the relationship between the NPK input to the catchment, and the area of arable lands and grasslands. These equations were used to estimate the NPK load for each part of studied catchment.

In the whole Raba River catchment the decrease of NPK load was closely correlated with the reduction of arable lands and the increase of the surface area of grasslands.

Despite marked decline of livestock density the load of NPK per surface area of meadows increased. This is an evidence that the newly created meadows (mainly from former arable lands) are very extensively used or not used at all (PIETRZAK, 2002). This is often so, because meadows are mown only in order to obtain direct subsidies from the European Union. The livestock are kept only for own needs of the farmers and their families.

\section{CONCLUSIONS}

1. There was a significant structural and spatial transformation in the upper Raba River catchment in the years 1980-2005. The most dynamic changes were noted in the second half of the 1990s and the beginning of the $21^{\text {st }}$ century.

2. Changes in the agricultural use consisted mainly in the decrease of the surface area of arable lands and the increase in that of meadows.

3. Animal production was reduced during the study period. The reduction manifested itself in the decrease of livestock density and was closely correlated with a decline of the area of agricultural lands, particularly of arable lands.

4. The surface area of meadows increased despite the decrease in livestock. This was due to natural succession of plants on arable lands. In practice, permanent grasslands are often kept only for direct subsidies obtained from the EU. 


\title{
REFERENCES
}

1. Dynowska I., Maciejewski M. (eds), 1991. Dorzecze górnej Wisły. (Upper Vistula River catchment). P. 1. Warszawa-Kraków, PWN: 1-341.

2. DYNOWSKA I., 1995. Wody. W: Karpaty Polskie, przyroda, człowiek i jego działalność. (Waters. In: Polish Carpathians, nature, man and his activity). Ed. J. Warszyńska. Kraków, Wydaw. UJ: 49-67.

3. ElANDT R., 1964. Statystyka matematyczna w zastosowaniu do doświadczalnictwa rolniczego. (Mathematical statistics applicable in agricultural experimentation). Warszawa, PWN: 1-595.

4. GREŃ J., 1982. Statystyka matematyczna - modele i zadania. (Mathematical statistics - models and tasks). Warszawa, PWN: 1-362.

5. GuZIK Cz., 1995. Rolnicze użytkowanie ziemi. W: Karpaty Polskie, przyroda, człowiek i jego działalność. (Agricultural land use. In: Polish Carpatians, nature, man and his activity). Ed. J. Warszyńska. Kraków, Wydaw. UJ: 239-242, 1-365.

6. KOPACZ M., 2007. Modelowanie zmian w jakości wód powierzchniowych na tle przeobrażeń użytkowo-przestrzennych w małych zlewniach górskich. W: Wpływ użytkowania małych zlewni górskich na występowanie i natężenie erozji wodnej. (Modelling of changes in surface water quality in response to utilitarian-spatial transformations in small mountain catchments. In: The influence of usage of small mountain catchments on occurrence and intensity of water erosion). Kraków, AR: 154164.

7. NiedbaŁa J., CzulaK J., 2000. Warunki i scenariusze hydrologiczne wezbrań. W: Model kompleksowej ochrony przed powodzią w obszarze dorzecza górnej Wisły na przykładzie województwa małopolskiego. (Hydrological conditions and courses of freshets. In: Model of complex flood protection in the area of upper Vistula River basin using the Malopolska Province as a case study). Ed. M. Maciejewski. Kraków, IMGW.

8. PIETRZAK S., 2002. Ocena potencjalnych strat azotu na podstawie bilansu w gospodarstwach rolnych o zróżnicowanym udziale użytków zielonych. (Evaluation of potential nitrogen losses upon the balance in farms with different grassland contribution). Woda Środowisko Obszary Wiejskie. Rozprawy naukowe i monografie, 2: 1-58.

9. SYMONIDES E., 2007. Ochrona przyrody. (Protection of nature). Warszawa, Wydaw. UW: 1-767.

10. TWARDY S., 2008. Karpackie użytki rolne jako obszary o niekorzystnych warunkach gospodarowania (ONW). (Carpathian agricultural lands as Less Favoured Areas (LFA)). Woda Środowisko Obszary Wiejskie, 8, 2b (24): 191-202.

11. TWARDY S., 2009. Tendencje zmian użytkowania przestrzeni rolniczej obszarów karpackich. (The trends in changes in use of the agricultural space in the area of Carpathians). Studia i Raporty IUNGPIB, 17: 49-58.

\section{STRESZCZENIE}

\section{Zmiany użytkowania obszarów rolniczych w latach 1980-2005 ze szczególnym uwzględnieniem TUZ na przykładzie zlewni górnej Raby}

\author{
Słowa kluczowe: jakość wód powierzchniowych, parametry produkcji rolniczej, \\ trwate użytki zielone, użytkowanie rolnicze
}

Celem pracy była ocena zmian w użytkowaniu rolniczym w długim czasie, ze szczególnym uwzględnieniem powierzchni pastwisk i łąk na tle przeobrażeń w rolnictwie w wybranych gminach, zlokalizowanych w górskich obszarach zlewni Raby. Zmiany w rolnictwie zostały opisane za pomocą wybranych parametrów pro- 
dukcyjnych, tj. obsady zwierząt gospodarskich wyrażonych w dużych jednostkach przeliczeniowych (DJP) oraz wprowadzanego na powierzchnię zlewni ładunku NPK. Określono relacje między strukturą użytkowania rolniczego a wyżej wymienionymi czynnikami produkcyjnymi. Wykazano, że istnieją ścisłe zależności między ograniczeniem produkcji rolniczej a zmianami w wielkości wprowadzanego ładunku składników biogennych do środowiska. To z kolei korelowało ze zmianami użytkowymi, głównie w zakresie użytkowania płużnego. Zwiększyła się natomiast powierzchnia łąk, które (ze względu na spadek pogłowia zwierząt gospodarskich) należy traktować jako ekstensywne użytkowane użytki zielone lub wręcz tereny zadarnione. Wnioski $\mathrm{z}$ pracy pomogą $\mathrm{w}$ optymalnym kształtowaniu przestrzeni użytkowej terenów górskich i pogórskich z zachowaniem zrównoważonego rozwoju badanego obszaru. 